\title{
PREVALENCE OF GENOTYPES IN HELICOBACTER PYLORI ISOLATES FROM PATIENTS IN EASTERN TURKEY AND THE ASSOCIATION OF THESE GENOTYPES WITH CLINICAL OUTCOME
}

\author{
Gokben Ozbey $^{1^{*}}$, Cem Aygun ${ }^{2}$ \\ ${ }^{1}$ Vocational School of Health Services, Firat University, 23119, Elazig, Turkey; ${ }^{2}$ Department of Gastroenterology, Faculty of \\ Medicine, Firat University, 23119, Elazig, Turkey.
}

Submitted: July 25, 2011; Returned to authors for corrections: December 22, 2011; Approved: June 07, 2012.

\begin{abstract}
There is not much information available regarding the prevalence of the genotypes of Helicobacter pylori isolates in Turkey, particularly in eastern Turkey. The aims of this study were to detect the prevalence of different genotypes of $H$. pylori in Turkish patients with gastrointestinal complaints and to determine the relationship of these genotypes with clinical outcome and sex. One hundred forty $H$. pylori isolates were examined for the presence of its genotypes by the PCR. We found that the prevalence of vacAs1, vacAs 2 , cagA, cagE, iceA1, iceA2 and babA2 genes were $88.6 \%, 11.4 \%, 71.4 \%, 35.7 \%, 41.4 \%, 58.6 \%$, and $62.1 \%$, respectively. The most predominant vacA subtype was s1a (81.4\%). The most vacA allelic combination detected were vacAs $1 \mathrm{~m} 1(65.2 \%)$ and $\mathrm{s} 1 \mathrm{~m} 2(53.9 \%)$ in patients with peptic ulcer and gastritis, respectively. The only vacAs1 isolate was significantly associated with gastritis and peptic ulcer $(\mathrm{p}<0.05)$. The vacAs1a, $\mathrm{ml}$, slml and babA2 genes were significantly associated with peptic ulcer $(\mathrm{p}<0.05)$, whereas $\mathrm{m} 2$ gene was significantly associated with only gastritis $(\mathrm{p}<0.05)$. The difference between sex and genotypes was statistically significant among the cagA, vacAs1, iceA2 and babA2 genes. This study reported for the first time the prevalence of $H$. pylori genotypes in patients with gastrointestinal complaints in eastern Turkey. Further studies are needed to understand epidemiological importance of the genotypes of H. pylori isolates in this region and the association between the virulence genes and clinical outcome in different regions.
\end{abstract}

Key words: Helicobacter pylori, prevalence, patient, genotypes, PCR.

\section{INTRODUCTION}

Helicobacter pylori (H. pylori) which infects more than half of the world's population, a major etiological agent in development of gastritis (G), peptic ulcer (PU) and gastric carcinoma (3). Scientists have been shown that several genes, such as the vacuolating cytotoxin (vacA), cytotoxin associated gene A ( $\operatorname{cag} A)$, cytotoxin associated gene $\mathrm{E}$ ( $c a g E)$, induced by contact with epithelium (iceA) and blood adhesion binding antigen ( $b a b A 2)$ have been determined and these genes may play important roles in the pathogenesis of $H$. pylori infection $(22,24)$.

*Corresponding Author. Mailing address: Vocational School of Health Services, Firat University, 23119, Elazig, Turkey.; Tel: +90 4242370079 Fax: +90 424 2415544.; E-mail: gokbenosbey@yahoo.com 
The cagA gene being a marker for the presence of the cag pathogenicity island (cagPAI) of approximaely $40 \mathrm{~kb}$ was the first gene found to be present in $H$. pylori strains (7) and its presence is associated with a more severe clinical outcome, such as PU, atrophic G, and gastric cancer $(\mathrm{GC})(4,5)$. The cagA induces interleukin-8 (IL-8) production and mucosal inflamation $(4,5)$. The cagPAI contains a gene known as cagE, is one of the marker genes in cagI of the cagPAI and it is required for translocation and phosphorylation $(9,28)$. The cagE gene was found to be associated with a more severe clinical outcome (11).

The vacA gene is present in all $H$. pylori strains and contains at least two variable parts (a hypervariable signal sequence and a middle region allele) (2). Among the vacA subtypes, subtypes $\mathrm{s} 1 \mathrm{a}, \mathrm{s} 1 \mathrm{~b}, \mathrm{~s} 1 \mathrm{c}$ and $\mathrm{s} 2$, and $\mathrm{m} 1, \mathrm{~m} 2 \mathrm{a}$ and $\mathrm{m} 2 \mathrm{~b}$ have been identified (30). Although all strains of $H$. pylori include the vacA gene, they vary in their ability to produce cytotoxin (8). Type $\mathrm{m} 1$ strains show more toxic activity than $\mathrm{m} 2$, type s1a is more active than $\mathrm{s} 1 \mathrm{~b}$, and type $\mathrm{s} 2$ is less active than s1 (2).

The recently discovered iceA gene exists in two main allelic variants of the gene, iceA1 and iceA2 (21). iceA1 is upregulated upon contact of $H$. pylori with the gastric epithelium (21) and is a marker for PU disease (31).

Blood adhesion binding antigen $\mathrm{A}$, encoded by the babA2 gene has been exhibited to mediate binding activity between bacterial adhesin and human Lewis-b blood group antigens on gastric epithelial cells (14). Although three $b a b A$ alleles have been identified (babA1, babA2 and babB), only the babA2 gene product is necessary for Lewis $b$ binding activity (14).

There is not much information available on determination of the genotypes of $\mathrm{H}$. pylori in Turkey, particularly in eastern Turkey where the overall incidence of $\mathrm{G}$ and $\mathrm{PU}$ are high. This study aimed 1) to detect the prevalence of the vacA, cagA, cagE, iceA1, iceA2 and babA2 genotypes in patients with $\mathrm{G}$ and PU, 2) to determine a possible association between clinical outcome and genotypes and 3) to identify any association between the genotypes and sex.

\section{MATERIALS AND METHODS}

\section{Patients}

A total of $140 \mathrm{H}$. pylori isolates (115 with G, 23 with PU, 2 with GC) identified by PCR from antral biopsies of 184 Turkish patients [17-92 years of age (average 49)] who underwent endoscopy at Firat University Hospital, Gastroenterology Department during 2009 and 2010. Approval of this study was obtained from the Medical Ethics Committee of Firat University. We received informed consent from all patients.

\section{DNA Extraction}

DNA samples was extracted by QIAamp DNA mini kit (Qiagen, Lot No: 11872534, Cat No: 51306) according to the manufacturer's instructions. The extracted DNA was stored at $20^{\circ} \mathrm{C}$ until used as template in PCR.

\section{PCR analysis of genotypes in $\mathrm{H}$. pylori isolates}

The primers used in this study and PCR conditions are shown in Table 1. For the cagA gene subtyping, primers CAGA-F and CAGA-R yielded a fragment of $298 \mathrm{bp}$ of the cagA gene were used (13). For analysis of the vacA s region, primers VA1-F, VA1-R, SS2-F, and SS3-F were used $(2,23$, 34). Primers VA1-F and VA1-R yielded a fragment of $259 \mathrm{bp}$ or $286 \mathrm{bp}$ in size for type s1 or s2 strains, respectively. For detection of the vacA $\mathrm{m}$ region, primers VAG-F and VAG-R generated a fragment of $567 \mathrm{bp}$ for $\mathrm{m} 1$ variants and a fragment of $642 \mathrm{bp}$ for $\mathrm{m} 2$ variants (23). For analysis of the cagE gene, primers CagE-F and CagE-R yielded a fragment of 508 bp of the cagE gene described by Tomasini et al. (28) were used. For detection of the iceA gene, primers iceA1-F, iceA1-R, iceA2-F, and iceA2-R were used (31). Primers iceA1-F and iceA1-R generated a fragment of $247 \mathrm{bp}$ for the iceA1 gene, and primers iceA2-F and iceA2-R generated a fragment of 229 or $334 \mathrm{bp}$ for the ice $A 2$ gene (31). For analysis of the babA2 gene, primers BABA2-F and BABA2-R described by Sheu et al. (27) were used. 
Amplification was performed in a reaction mixture $(50 \mu \mathrm{l}$ final volume) containing $25 \mu \mathrm{l}$ 2XPCR Master Mix (Fermentas, K01071), $15 \mu \mathrm{l}$ distilled water, $2.5 \mu \mathrm{l}$ of each primer and $400 \mathrm{ng}$ genomic DNA. The thermal cycling conditions performed with a touchdown thermal cycler (Hybaid, Middlesex, England). PCR product was analyzed on $1.5 \%$ agarose gel containing $0.5 \mu \mathrm{g} / \mathrm{ml}$ of ethidium bromide.

The DNAs of the HP 26695, HP J99 and some clinical isolates, provided by Dr. Yoshio Yamaoka from Michael E. DeBakey Veterans Affairs Medical Center, Houston, TX 77030, USA was used to confirm the PCR test as positive controls. Distilled water used as a negative control.

Table 1. Primers and PCR conditions used in our study.

\begin{tabular}{|c|c|c|c|c|}
\hline Genes & Sequence $\left(5^{\prime} \rightarrow 3^{\prime}\right)$ & Cycle Conditions & $\begin{array}{l}\text { Size (bp) of Expected } \\
\text { PCR product }\end{array}$ & $\begin{array}{c}\text { Reference } \\
\text { number }\end{array}$ \\
\hline cagA & $\begin{array}{l}\text { ATAATGCTAAATTAGACAACTTGAGCGA } \\
\text { TTAGAATAATCAACAAACATCACGCCAT }\end{array}$ & $94^{\circ} \mathrm{C}, 1 \mathrm{~min} ; 60^{\circ} \mathrm{C}, 1 \mathrm{~min} ; 72^{\circ} \mathrm{C}, 1 \mathrm{~min}(45$ cycles $)$ & 298 & 13 \\
\hline $\operatorname{vacA~s} 1 / \mathrm{s} 2$ & $\begin{array}{l}\text { ATGGAAATACAACAAACACAC } \\
\text { CTGCTTGAATGCGCCAAAC }\end{array}$ & $94^{\circ} \mathrm{C}, 1 \mathrm{~min} ; 52^{\circ} \mathrm{C}, 1 \mathrm{~min} ; 72^{\circ} \mathrm{C}, 1 \mathrm{~min}(35$ cycles $)$ & $259 / 286$ & 2,23 \\
\hline vacAs1a & $\begin{array}{l}\text { GTCAGCATCACACCGCAAC } \\
\text { CTGCTTGAATGCGCCAAAC }\end{array}$ & $94^{\circ} \mathrm{C}, 1 \mathrm{~min} ; 52^{\circ} \mathrm{C}, 1 \mathrm{~min} ; 72^{\circ} \mathrm{C}, 1 \mathrm{~min}(35$ cycles $)$ & 190 & 23 \\
\hline vacAs $1 b$ & $\begin{array}{l}\text { AGCGCCATACCGCAAGAG } \\
\text { CTGCTTGAATGCGCCAAAC }\end{array}$ & $94^{\circ} \mathrm{C}, 1 \mathrm{~min} ; 52^{\circ} \mathrm{C}, 1 \mathrm{~min} ; 72^{\circ} \mathrm{C}, 1 \mathrm{~min}(35$ cycles $)$ & 187 & 23 \\
\hline vacAs1c & $\begin{array}{l}\text { CTCTCGCTTTAGTGGGGYT } \\
\text { CTGCTTGAATGCGCCAAAC }\end{array}$ & $94^{\circ} \mathrm{C}, 1 \mathrm{~min} ; 52^{\circ} \mathrm{C}, 1 \mathrm{~min} ; 72^{\circ} \mathrm{C}, 1 \mathrm{~min}(35$ cycles $)$ & 213 & 34 \\
\hline $\operatorname{vacA} \mathrm{m} 1 / \mathrm{m} 2$ & $\begin{array}{l}\text { CAATCTGTCCAATCAAGCGAG } \\
\text { GCGTCAAAATAATTCCAAGG }\end{array}$ & $94^{\circ} \mathrm{C}, 1 \mathrm{~min} ; 52^{\circ} \mathrm{C}, 1 \mathrm{~min} ; 72^{\circ} \mathrm{C}, 1 \mathrm{~min}(35$ cycles $)$ & $567 / 642$ & 23 \\
\hline cagE & $\begin{array}{l}\text { TTGAAAACTTCAAGGATAGGATAGAGC } \\
\text { GCCTAGCGTAATATCACCATTACCC }\end{array}$ & $94{ }^{\circ} \mathrm{C}, 1 \mathrm{~min} ; 53^{\circ} \mathrm{C}, 45 \mathrm{~s} ; 72^{\circ} \mathrm{C}, 45 \mathrm{~s}$ ( 35 cycles $)$ & 508 & 28 \\
\hline iceA1 & $\begin{array}{l}\text { GTGTTTTTAACCAAAGTATC } \\
\text { CTATAGCCASTYTCTTTGCA }\end{array}$ & $95^{\circ} \mathrm{C} 1 \mathrm{~min} ; 57^{\circ} \mathrm{C}, 1 \mathrm{~s} ; 72^{\circ} \mathrm{C}, 1 \mathrm{~min}(35$ cycles $)$ & 247 & 31 \\
\hline iceA2 & $\begin{array}{l}\text { GTTGGGTATATCACAATTTAT } \\
\text { TTRCCCTATTTTCTAGTAGGT }\end{array}$ & $95^{\circ} \mathrm{C} 1 \mathrm{~min} ; 57^{\circ} \mathrm{C}, 1 \mathrm{~s} ; 72^{\circ} \mathrm{C}, 1 \mathrm{~min}(35$ cycles $)$ & 229 or 334 & 31 \\
\hline babA2 & $\begin{array}{l}\text { CCAAACGAAACAAAAAGCGT } \\
\text { GCTTGTGTAAAAGCCGTCGT }\end{array}$ & $94^{\circ} \mathrm{C}, 1 \mathrm{~min} ; 45^{\circ} \mathrm{C}, 1 \mathrm{~min} ; 72^{\circ} \mathrm{C}, 1 \mathrm{~min}(30$ cycles $)$ & 271 & 27 \\
\hline
\end{tabular}

\section{Statistical analysis}

The Fischer's exact and $\chi^{2}$ tests were used to compare the differences between $H$. pylori genotypes and clinical outcome and between the sex and genotypes. A p value of $<0.05$ was taken statistically significant.

\section{RESULTS}

The prevalence of $\operatorname{cag} A \operatorname{vac} A, \operatorname{cag} E$, ice $A$ and babA2 genes are shown in Table 2. Because the number of patients with GC is very low, the relationship between $H$. pylori genotypes in patients with GC was not determined.

The cagA gene was determined in 100 (71.4\%) of 140 isolates examined (Table 2). The vacA genes was found in all isolates we studied. All vacAm1 genotypes from patients were also vacAs1. The vacAsla $(81.4 \%)$ gene was found most frequently than vacAs $1 \mathrm{~b}(2.9 \%)$ and vacAs $1 \mathrm{c}(4.3 \%)$. The most vacA allelic combination was $\mathrm{s} 1 / \mathrm{m} 2(50.7 \%)$, followed by $\mathrm{s} 1 / \mathrm{m} 1 \quad(37.9 \%)$ and $\mathrm{s} 2 / \mathrm{m} 2(11.4 \%)$. In addition, the most common vacA allelic combination were vacAs $1 \mathrm{~m} 1$ (65.2\%) and $\operatorname{s} 1 \mathrm{~m} 2(53.9 \%)$ in patients with PU and G, respectively. No vacAs $2 \mathrm{~m} 1$ genotype was observed in our study. Seventy-four $(52.9 \%)$ isolates were found to be "triple positive" $\left(v a c A s 1^{+}\right.$cagA $\left.A^{+} b a b A 2^{+}\right)$(Table 2).

The prevalence of the cagE genotype was 50 (35.7\%), and it was found more commonly in patients with PU. The iceA genes were found in all isolates we studied. The iceA1 and 
iceA2 genes were detected in $58(41.4 \%)$ and $82(58.6 \%)$ isolates, respectively. The iceA1 gene was most frequently observed in patients $(60.9 \%)$ with PU, whereas iceA2 was most commonly found in patients $(63.5 \%)$ with $G$. The iceA2 isolates classified in two types according to PCR product size: 229 and $334 \mathrm{bp}$. The distribution of these two types were similar in the isolates examined (data not shown). The babA2 gene was observed in $87(62.1 \%)$ of all isolates studied (Table 2 and 3$)$.

The presence of the only vacAs1 isolate was significantly associated with G and PU $(\mathrm{p}<0.05)$. The vacAsla, ml, slml and babA2 genes were significantly associated with PU $(\mathrm{p}<0.05)$, whereas $\mathrm{m} 2$ gene was significantly associated with only $G$ $(\mathrm{p}<0.05)$. The cagA gene was significantly associated with $\mathrm{s} 1$, s1m1 and babA2 genotypes $(\mathrm{p}<0.05)$ (Table 3$)$.

The distribution of $H$. pylori genotypes and sex is shown in Table 4. The difference between sex and genotypes was statistically significant among the cagA, vacAs1, iceA2 and babA2 genes $(\mathrm{p}<0.05)$ (Table 4$)$.

Table 2. The prevalence of virulence genes in $H$. pylori isolates.

\begin{tabular}{|c|c|}
\hline Virulence genes & Prevalence (n) (\%) \\
\hline $\operatorname{cagA}$ & $100(71.4)$ \\
\hline vacAs1 & $124(88.6)$ \\
\hline vacAsla & $114(81.4)$ \\
\hline vacAs $1 \mathrm{~b}$ & $4(2.9)$ \\
\hline vacAslc & $6(4.3)$ \\
\hline vacAs2 & $16(11.4)$ \\
\hline vacAm1 & $53(37.9)$ \\
\hline vacAm2 & $87(62.1)$ \\
\hline vacAs $1 / \mathrm{m} 1$ & $53(37.9)$ \\
\hline vacAs $1 / \mathrm{m} 2$ & $71(50.7)$ \\
\hline vacAs $2 / \mathrm{m} 2$ & $16(11.4)$ \\
\hline $\operatorname{cag} \mathrm{E}$ & $50(35.7)$ \\
\hline iceA1 & $58(41,4)$ \\
\hline ісеА2 & $82(58.6)$ \\
\hline babA2 & $87(62.1)$ \\
\hline $\operatorname{vacAs} 1^{+} \operatorname{cagA}{ }^{+}$babA2 $2^{+}$ & $74(52.9)$ \\
\hline
\end{tabular}

Table 3. The prevalence of the genotypes in $140 \mathrm{H}$. pylori positive patients with $\mathrm{G}$ and $\mathrm{PU}$.

\begin{tabular}{|c|c|c|}
\hline Genotypes & $G(n=115)(\%)$ & PU $(n=23)(\%)$ \\
\hline $\operatorname{cagA}$ & $79(68.7)$ & $19(82.6)$ \\
\hline vacAs 1 & $99(86.1)^{*}$ & $23(100)^{*}$ \\
\hline vacAsla & $90(78.3)$ & $22(95.7)^{*}$ \\
\hline vacAs $1 \mathrm{~b}$ & $4(3.5)$ & $0(0)$ \\
\hline vacAslc & $5(4.3)$ & $1(4.3)$ \\
\hline vacAs 2 & $16(13.9)$ & $0(0)$ \\
\hline vacAm1 & $37(32.2)$ & $15(65.2)^{*}$ \\
\hline vacAm2 & $78(67.8)^{*}$ & $8(34.8)$ \\
\hline vacAs $1 / \mathrm{m} 1$ & $37(32.2)$ & $15(65.2)^{*}$ \\
\hline vacAs $1 / \mathrm{m} 2$ & $62(53.9)$ & $8(34.8)$ \\
\hline vacAs $2 / \mathrm{m} 2$ & $16(13.9)$ & $0(0)$ \\
\hline $\operatorname{cagE}$ & $39(33.9)$ & $10(43.5)$ \\
\hline iceA1 & $42(36.5)$ & $14(60.9)$ \\
\hline iceA2 & $73(63.5)$ & $9(39.1)$ \\
\hline babA2 & $68(59.1)$ & $17(73.9)^{*}$ \\
\hline $\operatorname{vacAs} 1^{+} \operatorname{cag} \mathrm{A}^{+} \operatorname{babA}^{+}$ & $59(51.3)$ & $13(56.5)$ \\
\hline
\end{tabular}

G, gastritis; PU, peptic ulcer, ${ }^{*}$ significant $\mathrm{p}<0.05$

Table 4. The association between the sex of $140 \mathrm{H}$. pyloripositive patients and its genotypes.

\begin{tabular}{|c|c|c|}
\hline Genotypes & $\begin{array}{c}\text { Male (70) } \\
\text { n (\%) }\end{array}$ & $\begin{array}{c}\text { Female (70) } \\
\text { n }(\%)\end{array}$ \\
\hline $\operatorname{cagA}$ & $53(75.7)^{*}$ & $47(67.1)$ \\
\hline vacA s1 & $66(94.3)^{*}$ & $58(82.9)$ \\
\hline vacA s2 & $4(5.7)$ & $12(17.1)$ \\
\hline vacA s1a & $58(82.9)$ & $56(80)$ \\
\hline vacA s $1 \mathrm{~b}$ & $3(4.3)$ & $1(1.4)$ \\
\hline vacA slc & $5(7.1)$ & $1(1.4)$ \\
\hline vacA m1 & $31(44.3)$ & $22(31.4)$ \\
\hline vacA $\mathrm{m} 2$ & $39(55.7)$ & $48(68.6)$ \\
\hline vacA s $1 / \mathrm{m} 1$ & $31(44.3)$ & $22(31.4)$ \\
\hline vacA s $1 / \mathrm{m} 2$ & $35(50)$ & $36(51.4)$ \\
\hline $\operatorname{vacA} \mathrm{s} 2 / \mathrm{m} 2$ & $4(5.7)$ & $12(17.1)$ \\
\hline $\operatorname{cag} \mathrm{E}$ & $28(40)$ & $22(31.4)$ \\
\hline iceA1 & $20(28.6)$ & $38(54.3)$ \\
\hline iceA2 & $50(71.4)^{*}$ & $32(45.7)$ \\
\hline babA2 & $50(71.4)^{*}$ & $37(52.9)$ \\
\hline $\operatorname{vacAs}^{+} \mathrm{cagA}^{+} \mathrm{babA}^{+}$ & $45(64.3)$ & $29(41.4)$ \\
\hline
\end{tabular}

The number of studies related to genotypes of $H$. pylori in Turkey is seldom, and the data on the relationship of the genotypes and gastrointestinal diseases have been still disputable (8).

The $\operatorname{cag} A$ prevalence is different in every part of the world. The prevalence of cagA gene in this study was $71.4 \%$. 
This finding is in agrement with reports from Western countries $(22,24)$ but lower than reports from East Asian countries where the cagA are present in more than $90 \%$ of cases (33). In addition, the results of this study are consistent with previous reports $(6,29)$ which no association was found between cagA gene and PU. However, some studies have been reported that cagA gene was statistically associated with PU $(10,20,26)$.

The different results have also been reported in studies related to the vacA gene of $H$. pylori strains. In the present study, the vacA gene was observed in all strains. Our finding was similar to previous reports from Turkey $(10,25,26)$, Northern and Eastern European countries (32) where s1a gene was predominant genotype, but in contrast to a report from Korea (16). We detected a low prevalence of vacAs $1 \mathrm{~b}$ in this study which was contrast to pevious reports in Portugal, Central and South America (32). No vacAs1c genotype was determined except for the only one study reported in Turkey (18). In this study, the prevalence of the vacAs1c gene was found to be low. This may be related to low prevalence of GC in Turkey as stated in a study carried out by Erzin et al. (10).

We found that no $\mathrm{s} 1 \mathrm{~b}, \mathrm{~s} 1 \mathrm{c}$ and $\mathrm{s} 2$ genotypes associated with $\mathrm{G}$ and PU. Our data similar to previous reports in Turkey where vacAs1a strains were showed to be significantly associated with PU $(10,18)$, but different from a study in Turkey reported that vacAs1a strains were not found to be statistically associated with PU (26).

Our results supported the findings of the studies performed in Turkey and other countries $(3,6,10,18)$ where the $\mathrm{s} 1 \mathrm{~m} 2$ genotype was the most common gene combinations of the vacA, but contrary to studies $(8,26)$ reported that $\mathrm{s} 1 \mathrm{~m} 1$ genotype was the most predominant gene. The prevalence of $\mathrm{s} 2 \mathrm{~m} 2$ genotype was determined as $11.4 \%$ and all of $\mathrm{s} 2 \mathrm{~m} 2$ positive isolates were cagA negative. No s $2 \mathrm{~m} 1$ genotype was found in this study. This finding correlated confirm few data reported from other geographic regions of Turkey $(6,10,18)$. On the other hand, this study confirmed the findings of previous reports $(6,8,10,29)$ where there was no significant association between vacAs $1 \mathrm{~m} 2$ genotype, $\mathrm{G}$ and PU disease.

The prevalence $(35.7 \%)$ of cagE in this study is lower than other studies conducted in USA (64\%) (22), Turkey (59.3\%) (10), UK (71.2\%) (15) and Thailand (88.4\%) (8) but higher than a previous study in Turkey (28.6\%) (25). In an attempt to detect association between the cagE gene and PU, Fallone et al. (11), Day et al. (9) and Erzin et al. (10) have reported a significant association between the cagE gene and $\mathrm{PU}$ which is contrast to our findings.

In contrast to the results reported in China, Japan, Korea and Netherlands where the iceA1 gene was predominant (16, $20,31)$, the iceA2 gene was detected to be predominant genotype in this study. This result is in agreement with previous reports that the iceA2 gene was found to be prevalent in Brazilian, European and American patients (1, 20, 22).

Our results were similar to a previous study (1) reported that the distribution of iceA2 229 and 334-bp amplicon was found to almost the same in $H$. pylori strains. The results of the present study are similar to previous studies that no significant association between the iceA1 gene and PU have found in Brazilian and Turkish patients $(1,6,10)$, but in contrast to those reported by Peek et al. (21) and van Doorn et al. (31), who showed the association between the presence of iceA1 gene and PU. The iceA2 was more frequently observed in males than in females. Similar result have been reported by Ashour et al. (1).

The prevalence of the babA2 genotype in H. pylori strains varied in different countries of world. The prevalence of the babA2 was $34-72 \%$ in Western countries $(12,19,29)$ while it was $80-100 \%$ in Asian countries (16). We found a higher prevalence $(62.1 \%)$ of $b a b A 2$ than the result (53.8\%) reported in a previous study (10) in Turkey. Erzin et al. (10) had used the primers described by Gerhard et al. (12), we used the primers of Sheu et al. (27) which exhibited a high prevalence of $b a b A$ (8). A low prevalence of the $b a b A 2$ gene was detected when the primers described by Gerhard et al. (12) were used $(12,20)$. These primers amplifies 832 bp (12) in a highly variable region, associated with false negative PCR due to allelic 
variation (19). This study showed a highly significant association between the babA2 gene and PU disease, concurring with the previous studies $(12,29)$. This state may be explained by allelic variation in the babA gene which could have a variable affect in the different geographic regions of a country (19).

Regarding the relationship with genotypes in each isolate, we found to be an association between the cagA stratus and the vacAs1 genotype in present study which was similar with previous findings $(12,26,29,32)$. In addition, our study showed significantly association between the babA2 and the vacAs1 in contrast to the results reported by Erzin et al. (10) and Torres et al. (29).

In regard to the association with the distribution of $H$. pylori genotypes and sex in this study, the association was statistically significant among the cagA, vacAs1, iceA2 and babA2 genes. In a study conducted by Mansour and colleagues (17), there was no significant association between cagA gene and sex, but the association was statistically significant among the vacA, iceA and oipA genes (17).

This study reported the prevalence of the genotypes in $H$. pylori isolates in Elazig province located in the East of Turkey for the first time. However, the multicenter and large scale studies are needed to help us better understand epidemiological importance of this disease and the association between $H$. pylori genotypes and clinical outcome in different regions and populations.

\section{ACKNOWLEDGEMENTS}

We acknowledge Dr. Yoshio Yamaoka (Michael E. DeBakey Veterans Affairs Medical Center, Houston, TX 77030, USA) for supplying the DNAs of the HP 26695, HP J99 and some clinical isolates, Dr. Hans-Jurg Monstein (Division of Clinical Microbiology, Department of Clinical and Experimental Medicine, Faculty of Health Sciences, Linköping University, Linköping, Sweden), Dr. Gireesh Rajashekara (Food Animal Health Research Program, Ohio Agricultural Research and Development Center, Department of Veterinary
Preventive Medicine, The Ohio State University, Wooster, OH, USA) and Dr. Gilmara Coelho Meine (Postgraduation Program in Gastroenterology, Universidade Federal do Rio Grande do Sul, Brazil) for their suggestions and the constructive criticism of the manuscript, and Dr. Yakut Akyon Yilmaz, Department of Medical Microbiology, Faculty of Medicine, Hacettepe University, Ankara, Turkey for her technicial support and help. In addition, the authors thank to the management of the Elazig Veterinary Control and Research Institute for providing laboratory facilities during our study. This work was part of the project supported by the Scientific Research Council of Firat University (FUBAP 1609).

\section{REFERENCES}

1. Ashour, A.A.R.; Collares, G.B.; Mendes, E.N.; de Gusmão, V.R.; Queiroz, D.M.M.; Magalhães, P.P.; Carvalho, A.S.T.; Oliveira, C.A.; Nogueira, A.M.M.F.; Rocha, G.A.; Rocha, A.M.C. (2001). iceA genotypes of Helicobacter pylori strains isolated from Brazilian children and adults. J. Clin. Microbiol. 39, 1746-1750.

2. Atherton, J.C.; Cao, P.; Peek, R.M. Jr.; Tummuru, M.K.; Blaser, M.J.; Cover T.L. (1995). Mosaicism in vacuolating cytotoxin alleles of Helicobacter pylori. Association of specific vacA types with cytotoxin production and peptic ulceration. J. Biol. Chem. 270, 17771-17777.

3. Atherton, J.C. (1997). The clinical relevance of strain types of Helicobacter pylori. Gut. 40, 701-703.

4. Atherton, J.C. (2000). CagA: a role at last. Gut. 47, 33-41.

5. Blaser, M.J.; Perez-Perez, G.I.; Kleanthous, H.; Cover, T.L.; Peek, R.M.; Chyou, P.H.; Stemmermann, G.N.; Nomura, A. (1995). Infection with Helicobacter pylori strains possessing cagA is associated with an increased risk of developing adenocarcinoma of the stomach. Cancer Res. 55, 2111-2115.

6. Caner, V.; Yilmaz, M.; Yonetci, N.; Zincir, S.; Karagenc, N.; Kaleli, I.; Bagci, H. (2007). H. pylori iceA alleles are disease-specific virulence factors. World J. Gastroenterol. 13, 2581-2585.

7. Censini, S.; Lange, C.; Xiang, Z.; Crabtree, J.E.; Ghiara, P.; Borodovsky, M.; Rappuoli, R.; Covacci, A. (1996). cag, a pathogenicity island of Helicobacter pylori, encodes type I-specific and disease-associated virulence factors. Proc. Nat. Acad. Sci. USA. 93, 14648-14653.

8. Chomvarin, C.; Namwat, W.; Chaicumpari K.; Mairiang, P.; Sangchan, A.; Sripa, B.; Tor-Udom, S.; Vilaichone, R.K. (2008). Prevalence of Helicobacter pylori vacA, cagA, cagE, iceA and babA2 genotypes in Thai dyspeptic patients. Int. J. Infect. Dis. 12, 30-36.

9. Day, A.S.; Jones, N.L.; Lynett, J.T.; Jennings, H.A.; Fallone, C.A.; Beech, R.; Sherman, P.M. (2000). cagE is a virulence factor associated 
with Helicobacter pylori-induced duodenal ulceration in children. J. Infect. Dis. 181, 1370-1375.

10. Erzin, Y.; Koksal, V.; Altun, S.; Dobrucali, A.; Aslan, M.; Erdamar, S.; Dirican, A.; Kocazeybek, B. (2006). Prevalence of Helicobacter pylori vacA, cagA, cagE, iceA, babA2 genotypes and correlation with clinical outcome in Turkish patients with dyspepsia. Helicobacter 11, 574-580.

11. Fallone, C.A.; Barkun, A.N.; Gottke, M.U.; Beech, R.N. (1998). A review of the possible bacterial determinants of clinical outcome in Helicobacter pylori infection. Can. J. Microbiol. 44, 201-210.

12. Gerhard, M.; Lehn, N.; Neumayer, N.; Borén, T.; Rad, R.; Schepp, W.; Miehlke, S.; Classen, M.; Prinz, C. (1999). Clinical relevance of the Helicobacter pylori gene for blood-group antigen-binding adhesin. Proc. Natl. Acad. Sci. USA. 96, 12778-12783.

13. Hamlet, A.; Thoreson, A.C.; Nilsson, O.; Svennerholm, A.M.; Olbe, L (1999). Duodenal Helicobacter pylori infection differs in cagA genotype between asymptomatic subjects and patients with duodenal ulcers. Gastroenterology 116, 259-268.

14. Ilver, D.; Arnqvist, A.; Ogren, J.; Frick, I.M.; Kersulyte, D.; Incecik, E.T.; Berg, D.E.; Covacci, A.; Engstrand, L.; Boren, T. (1998). Helicobacter pylori adhesin binding fucosylated histo-blood group antigens revealed by retagging. Science. 279, 373-377.

15. Kauser, F.; Hussain, M.A.; Ahmed, I.; Srinivas, S.; Devi, S.M.; Majeed, A.A.; Rao, K.R.; Khan, A.A.; Sechi, L.A.; Ahmed, N. (2005). Comparative genomics of Helicobacter pylori isolates recovered from ulcer disease patients in England. BMC Microbiol. 5, 32.

16. Kim, S.Y.; Woo, C.W.; Lee, Y.M.; Son, B.R.; Kim, J.W.; Chae, H.B.; Youn, S.J.; Park, S.M. (2001). Genotyping cagA, vacA subtype, iceA1, and babA of Helicobacter pylori isolates from Korean patients, and their association with gastroduodenal diseases. J, Korean Med. Sci. 16, 579584.

17. Mansour, K.B.; Fendri, C.; Zribi, M.; Masmoudi, A.; Labbene, M.; Fillali, A.; Mami, N.B.; Najjar, T.; Meherzi, A.; Sfar, T.; Burucoa, C. (2010). Prevalence of Helicobacter pylori vacA, cagA, iceA and oipA genotypes in Tunisian patients. Ann. Clin. Microbiol. Antimicrob. 9, 10.

18. Nagiyev, T.; Yula, E.; Abayli, B.; Koksal, F. (2009). Prevalence and genotypes of Helicobacter pylori in gastric biopsy specimens from patients with gastroduodenal pathologies in the Cukurova region of Turkey. J. Clin. Microbiol. 47, 4150-4153.

19. Olfat, F.O.; Zheng, Q.; Oleastro, M.; Voland, P.; Boren, T.; Karttunen, R.; Engstrand, L.; Rad, R.; Prinz, C.; Gerhard, M. (2005). Correlation of the Helicobacter pylori adherence factor BabA with duodenal ulcer disease in four European countries. FEMS Immunol Med Microbiol 44, 151-156.

20. Oliveira, A.G.; Santos, A.; Guerra, J.B.; Rocha, G.A.; Rocha, A.M.; Oliveira, C.A.; Cabral, M.M.; Nogueira, A.M.; Queiroz, D.M. (2003). babA2- and cagA-positive Helicobacter pylori strains are associated with duodenal ulcer and gastric carcinoma in Brazil. J. Clin. Microbiol. 41,
3964-3966.

21. Peek, R.M.J.; Thompson, S.A.; Donahue, J.P.; Tham, K.T.; Atherton, J.C.; Blaser, M.J.; Miller, G.G. (1998). Adherence to gastric epithelial cells induces expression of a Helicobacter pylori gene, iceA, that is associated with clinical outcome. Proc. Am. Assoc. Phys. 110, 531-544.

22. Podzorski, R.P.; Podzorski, D.S.; Wuerth, A.; Tolia, V. (2003). Analysis of the vacA, cagA, cagE, iceA, and babA2 genes in Helicobacter pylori from sixty-one pediatric patients from the Midwestern United States. Diagn. Microbiol. Infect. Dis. 46, 83-88.

23. Qiao, W.; Hu, J.L.; Xiao, B.; Wu, K.C.; Peng, D.R.; Atherton, J.C.; Xue, H. (2003). cagA and vacA genotype of Helicobacter pylori associated with gastric diseases in Xi' an area. World J Gastroenterol 9, 1762-1766.

24. Ribeiro, M.L.; Godoy, A.P.; Benvengo, Y.H.; Mendonca, S.; Pedrazzoli, J. (2003). Clinical relevance of the cagA, vacA and ice A genotypes of Helicobacter pylori in Brazilian clinical isolates. FEMS Immunol. Med. Microbiol. 36, 181-185.

25. Salih, B.A.; Abasiyanik, M.F.; Ahmed, N. (2007). A preliminary study on the genetic profile of cag pathogenicity-island and other virulent gene loci of Helicobacter pylori strains from Turkey. Infect. Genet. Evol. 7, 509-512.

26. Saribasak, H.; Salih, B.A.; Yamaoka, Y.; Sander, E. (2004). Analysis of Helicobacter pylori genotypes and correlation with clinical outcome in Turkey. J. Clin. Microbiol. 42, 1648-1651.

27. Sheu, B.S.; Sheu, S.M.; Yang, H.B.; Huang, A.H.; Wu, J.J. (2003). Host gastric Lewis expression determines the bacterial density of Helicobacter pylori in babA2 genopositive infection. Gut 52, 927-932.

28. Tomasini, M.L.; Zanussi, S.; Sozzi, M.; Tedeschi, R.; Basaglia, G.; De Paoli, P. (2003). Heterogeneity of cag genotypes in Helicobacter pylori isolates from human biopsy specimens. J. Clin. Microbiol. 41, 976-980.

29. Torres, L.E.; Melian, K.; Moreno, A.; Alonso, J.; Sabatier, C.A.; Hernandez, M.; Bermúdez, L.; Rodríguez, B.L. (2009). Prevalence of vacA, cagA and babA2 genes in Cuban Helicobacter pylori isolates. World J. Gastroenterol. 15, 204-210.

30. van Doorn, L.-J.; Figueiredo, C.; Sanna, R.; Pena, S.; Midolo, P.; Ng, E.K.W.; Atherton, J.C.; Blaser, M.J.; Quint, W.G.V. (1998a). Expanding allelic diversity of Helicobacter pylori vacA. J. Clin. Microbiol. 36, 2597-2603.

31. van Doorn, L.J.; Figueiredo, C, Sanna, R, Plaisier A, Schneeberger PW, de Boer W, Quint W (1998b) Clinical relevance of the $\operatorname{cagA}$, vacA, and iceA status of Helicobacter pylori. Gastroenterology. 115:58-66.

32. van Doorn, L.J.; Figueiredo, C.; Megraud, F.; Pena, A.S.; Midolo, P.; Queroz, D.M.; Carnero, F.; Pegado, M.D.; Sanna, R. (1999). Geographic distribution of vacA allelic types of Helicobacter pylori. Gastroenterology. 116, 823-830.

33. Yamaoka, Y.; Kodama, T.; Gutierrez, O.; Kim, J.G.; Kashima, K.; Graham, D.Y. (1999). Relationship between Helicobacter pylori iceA, $\operatorname{cag} A$, and vacA status and clinical outcome: studies in four different 
countries. J. Clin. Microbiol. 37, 2274-2279.

34. Yamazaki, S.; Yamakawa, A.; Okuda, T.; Ohtani, M.; Suto, H.; Ito, Y.; Yamazaki, Y.; Keida, Y.; Higashi, H.; Hatakeyama, M.; Azuma, T.
(2005). Distinct diversity of vacA, cagA, and cagE genes of Helicobacter pylori associated with peptic ulcer in Japan. J. Clin. Microbiol. 43, 39063916.

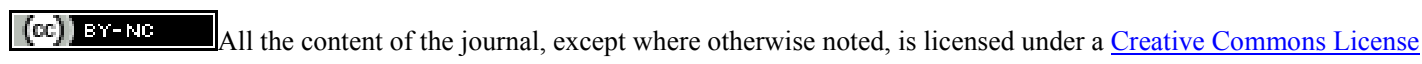

